\title{
Application of Connecting Learning Model- Organizing-Reflecting-Extending on The Ordinary Differential Equations Course
}

\author{
$1^{\text {st }}$ Yarman \\ Department of Mathematics, Faculty of \\ Mathematics and Natural Sciences, \\ Universitas Negeri Padang \\ Padang, Indonesia \\ yarman@fmipa.unp.ac.id \\ $4^{\text {th }}$ Armiati \\ Mathematics and Science Faculty \\ Universitas Negeri Padang \\ Padang, Indonesia \\ armiati@fmipa.unp.ac.id
}

\author{
$2^{\text {nd }}$ Ahmad Fauzan \\ Department of Mathematics, Faculty of \\ Mathematics and Natural Sciences, \\ Universitas Negeri Padang \\ Padang, Indonesia \\ fauzan_math@fmipa.unp.ac.id
}

\author{
$3^{\text {rd }}$ Lufri \\ Department of Mathematics, Faculty of \\ Mathematics and Natural Sciences, \\ Universitas Negeri Padang \\ Padang, Indonesia \\ lufri@fmipa.unp.ac.id
}

\begin{abstract}
One of the basic abilities expected by each student in the Ordinary Differential Equations (ODE) course is the understanding of the ODE concept. But the reality shows that students are still weak in understanding the concept. This indication is seen from student learning outcomes that are still relatively low. This situation is expected to occur because lectures that have not involved many students actively rediscover ODE concepts. Possible efforts to improve understanding of this concept by students are by applying the Connecting-Organizing-Extending Reflecting (CORE) learning model. This type of research is quasi-experimental with the design of the Static Group Comparison Design. The population of this study were students of the Mathematics Department FMIPA Universitas Negeri Padang in the January-June 2018 semester. The instrument used was the final test in the form of essays to see the understanding of concepts. Based on the results of the study, it was concluded that understanding the mathematical concepts of students who study with the CORE model is better than students who learn with conventional learning.
\end{abstract}

Keywords- Concept understanding, CORE learning model, conventional learning

\section{INTRODUCTION}

Differential equation is an equation that contains functions and derivatives. A differential equation that contains an ordinary derivative, that is, an instance of a function with an independent variable called an ordinary differential equation (Ordinary Differential Equations (ODE)). Whereas differential equations which contain partial derivatives, namely derivatives of functions with more than one independent variable, the equation is called a partial differential equation. This differential equation is much needed in solving real problems, both in the field of mathematics itself and in other fields such as engineering, biology, physics, chemistry, medicine, psychology, economics and so on.
With such broad scope applied from this differential equation, so that some universities make the ODE subject as a compulsory subject for their students. In addition to being a subject that is required in several universities, this course is also viewed as a very important subject. Differential equations other than those needed in mathematics are also needed in science and social sciences. In addition, the importance of this ODE course has also attracted the attention of many researchers both from outside and within the country [1]. The focus of their research in general is on the content and learning process of differential equations.

Research conducted by Arslan for example, he took a sample of his research successful students find algebraic solutions from a differential equation. In this study researchers tried to express understanding of concepts and difficulties of students about the solution of the differential equations they had obtained [1]. For this purpose, there were 13 questions submitted to 77 students who were assigned as research samples, consisting of 6 questions about algebraic solutions, and 7 questions about the interpretation of differential equations and their solutions. From the analysis of student answers, it was concluded that students who succeeded in getting algebraic solutions did not fully understand the concepts related to the interpretation of the algebraic solutions obtained, and they had serious difficulties with this concept. In other words, the results of this study indicate the need for a more in-depth study of understanding the basic concepts of differential equations.

In connection with the results of this study, Crozer and Baker also conducted research on differential equality courses for Ohio State University Engineering Faculty students [2]. This subject is the required course here because in some advanced engineering courses requires knowledge contained in the differential equation courses. Unfortunately from the research conducted by Crozer and Baker the results were very disappointing. The results of his research show that engineering students who have passed the differential 
equality courses are unable to understand and apply differential equations in advanced engineering courses.

One of the reasons is because the implementation of the lecture on differential equation in the Ohio State University Faculty of Engineering requires students to master differential equations in the abstract first, before they understand or apply them in engineering and other fields [2]. This is in line with the structure of differential equation reference books that they use which are more abstract and procedural, only prioritizing calculations that are analytical in nature. This condition results in the learning of differential equations being less meaningful.

This lack of meaning in learning differential equations contributed to the inability of students to apply differential equations to several advanced engineering courses. Not satisfied with the results of the research above, Czocher continued the research entitled "Examining the Relationship between Contextual Mathematics Instruction and Performance of Engineering Students". In this study the researchers tried to compare the learning outcomes between the two groups of engineering students who attended the lecture on differential equations [3]. The first group is students whose learning of differential equations is traditionally given and the other groups are students who apply contextual-based curriculum.

In traditional learning, students solve differential equations by using analytical techniques in accordance with pre-existing procedures. In this case students are not directed to solve contextual problems that are applicable. Whereas for students whose learning uses a contextual-based curriculum, oriented to solve contextual problems that are applicable. The results of this study concluded that the application of contextual-based curriculum in learning differential equations in Faculty of Engineering students provided better learning outcomes compared to students given traditional learning. Based on the results of these studies it appears that the contextual approach has a better effect on learning, especially in terms of solving applied problems, including learning differential equations.

In addition, based on the experience of researchers fostering ODE courses at the Mathematics Department of the Faculty of Mathematics and Natural Sciences, Padang State University, students were still weak in understanding concepts. This indication is seen from student learning outcomes that are still relatively low. This situation is expected to occur because lectures that have not involved many students actively rediscover ODE concepts. The concept is the fruit of the human abstract mind, which is the result of generalization of many experiences (objects, events, or facts) related systematically [4]. Concept understanding is the level of ability that expects students to be able to understand known concepts, situations, and facts, and can explain in their own words according to their knowledge without changing meaning.

To be able to engage students actively, it is necessary to choose the right learning approach. Among the learning models that are able to seek student participation in constructing concepts are the learning models Connecting, Organizing, Reflecting and Extending (CORE). The CORE model is an innovative learning model that can be used to enable students to build their own knowledge [5]. In this learning model, learning activities are centered on students, lecturers act more as facilitators, motivators, and mediators. The CORE model also conditions students to be able to think more broadly about the information they obtain.

The CORE model includes 4 interrelated words that have a unified function. Connecting to CORE is used to train students' memory related to old information and use it to learn new concepts. Organizing activities help students organize ideas that they already have to understand the next concept. Reflecting activities play a role in inviting students to rethink the ideas they already have, explore, explore and strengthen the information they have obtained, and train them to explain the information they have obtained. Then extending activities as activities to develop and use information that has been obtained by working on problem exercises so that understanding of the concepts they have gained is deeper and more lasting.

The focus of the CORE learning model is on students' thinking ability in connecting, organizing, exploring, managing, and developing information obtained. This CORE model combines four important constructivist elements, which are connected to students' knowledge, regulates new content (knowledge) of students to broaden knowledge [6]. More simply, this CORE model is a learning model that expects students to be able to construct their own knowledge by connecting and organizing their old knowledge with their new knowledge, then thinking about that knowledge again and hopefully students can expand that knowledge when the learning process takes place.

The CORE learning model conducted with group discussion can make students more free in their opinions, find solutions to mathematical problems, and build their own understanding. This is expected to improve the ability to understand students' mathematical concepts.

Based on the description above, the authors are interested in conducting research with the title: Application of the Connecting-Organizing-Reflecting-Extending Learning Model on the Ordinary Differential Equation Course.

\section{METHOD}

The type of research used is quasi-experimental research with its research design Static Group Comparison Design [7]. In this design, learning is applied using CORE learning models in the experimental class, while in the control class with conventional learning. As a population in this study were students of the Department of Mathematics, Faculty of Mathematics and Natural Sciences, Padang State University, January-June 2018 semester.

The instrument used in this study is a test of understanding the concept of ODE in the form of an essay form test. To get a good test, the test questions were tested and analyzed the test results. The data used in the form of the students' ODE concept comprehension test results were assessed by using the scoring rubric of understanding mathematical concepts.

\section{RESULTS AND DISCUSSION}

Data from the concept comprehension test results were obtained from the test followed by 34 students in the experimental class, and 36 students in the control class. The results of the test analysis can be seen in Table I. 
TABLE I. RESUlTS OF UNDERSTANDING STUDENT CONCEPT TEST

\begin{tabular}{|c|c|c|c|c|c|}
\hline Class & $\mathrm{N}$ & $\overline{\bar{x}}$ & $\mathrm{~S}$ & $\overline{\boldsymbol{x}}_{\max }$ & $\overline{\bar{x}}_{\min }$ \\
\hline Experiment & 34 & 64,0 & 8,49 & 89,3 & 46,36 \\
\hline Control & 36 & 53,75 & 13,21 & 86,7 & 34,27 \\
\hline
\end{tabular}

In Table I, it can be seen that the average understanding of the concept of experimental class students is higher than the control class. Judging from the standard deviation, the standard deviation of the experimental class is lower than the standard deviation of the control class, which means that the experimental class value is more uniform than the control class.

Furthermore, data on understanding the concept of students was analyzed for each item of the item in accordance with indicators of understanding mathematical concepts. Students' ability in each concept understanding concept is given a score of $0,1,2,3$, or 4 according to criteria based on the concept understanding scoring rubric [8]. In the following Table 2 can be seen the number and percentage of students who get scores on each indicator of understanding the concept.

Table II. Percentage of Understanding of Student ConcePts Per CONCEPT UNDERSTANDING INDICATORS

\begin{tabular}{|c|c|c|c|c|c|c|}
\hline \multirow[t]{2}{*}{ Indicators } & \multirow[t]{2}{*}{ Class } & \multicolumn{5}{|c|}{ Percentage of Students who get a score } \\
\hline & & 0 & 1 & 2 & 3 & 4 \\
\hline \multirow{2}{*}{$\begin{array}{l}\text { Restate the } \\
\text { concept }\end{array}$} & Experiment & 0,00 & 0,00 & 0,00 & 14,35 & 85,65 \\
\hline & Control & 0,00 & 0,00 & 3,38 & 9,50 & 87,13 \\
\hline \multirow{2}{*}{$\begin{array}{l}\text { Give examples } \\
\text { and not } \\
\text { examples }\end{array}$} & Experiment & 0,00 & 0,00 & 28,63 & 31,13 & 40,50 \\
\hline & Control & 0,00 & 0,00 & 21,25 & 46,87 & 31,89 \\
\hline \multirow[t]{2}{*}{ Classify objects } & Experiment & 0,00 & 0,00 & 0,00 & 2,79 & 97,21 \\
\hline & Control & 3,38 & 0,00 & 0,00 & 9,50 & 87,13 \\
\hline \multirow{2}{*}{$\begin{array}{l}\text { Identify the } \\
\text { properties of } \\
\text { the operation } \\
\text { or concept. }\end{array}$} & Experiment & 0,00 & 0,00 & 3,25 & 81,63 & 15,12 \\
\hline & Control & 15,87 & 46,60 & 15,89 & 21,66 & 0,00 \\
\hline \multirow{2}{*}{$\begin{array}{l}\text { Applying the } \\
\text { concept } \\
\text { logically. }\end{array}$} & Experiment & 0,00 & 3,83 & 0,00 & 42,01 & 54,17 \\
\hline & Control & 12,88 & 3,50 & 12,00 & 21,50 & 50,13 \\
\hline \multirow{2}{*}{$\begin{array}{c}\text { Presenting } \\
\text { concepts in } \\
\text { various forms } \\
\text { mat } \\
\text { representation. } \\
\text { (tables, } \\
\text { diagrams, } \\
\text { graphs) }\end{array}$} & Experiment & 9,75 & 0,00 & 46,38 & 43,88 & 0,00 \\
\hline & Control & 46,13 & 3,88 & 31,75 & 18,25 & 0,00 \\
\hline \multirow{2}{*}{$\begin{array}{l}\text { Link various } \\
\text { concepts inside } \\
\text { mathematics } \\
\text { and outside } \\
\text { mathematics }\end{array}$} & Experiment & 68,63 & 15,75 & 6,38 & 9,25 & 0,00 \\
\hline & Control & 65,13 & 3,63 & 3,75 & 18,38 & 9,13 \\
\hline \multirow{2}{*}{$\begin{array}{l}\text { Develop } \\
\text { requirements } \\
\text { and / or } \\
\text { requirements } \\
\text { enough } \\
\text { conditions for a } \\
\text { concept }\end{array}$} & Experiment & 28,25 & 6,13 & 18,13 & 28,73 & 18,77 \\
\hline & Control & 53,10 & 25,03 & 12,58 & 0,00 & 9,30 \\
\hline
\end{tabular}

In Table II can be seen in general the understanding of the concept of students in the experimental class is better than the control class students. Further explained about understanding students' mathematical concepts based on the indicators observed, namely. From Table II it can be seen that the two sample classes have been able to in indicator 1, which is to reiterate an ODE concept that has been studied. Indicators providing examples or examples of counter (not examples) of the concepts studied can be seen in number 2 test questions. Based on these questions, students are required to be able to determine the example of a differential equation which is included in the first order diffrential equation. In this indicator, the average value of the experimental class students is higher than the control class students. But because the difference in value is not too far away, this means that the two sample classes have been able to provide good examples.

In the indicator classifying objects (questions number 3), this problem requires students to classify differential equations based on order, degree, and linearity. The average value of the experimental class students and the control class on this indicator. It can also be said that the two sample classes have been able to calcify differential equations based on certain properties. Meanwhile on indicators identifying the nature of operations or concepts can be seen in problem number 4 . The problem requires students to determine the method of solving a differential equation. In this indicator, the average score of the experimental class score is higher than the control class. From table 2, it can be seen that experimental class students are better at identifying the nature of operations or concepts.

Indicators of applying the concept logically can be seen in problem number 5. In this indicator, the average score of the experimental class students is higher than the control class students. This means that experimental class students are better at applying the concept logically compared to control class students.

Furthermore, the indicators present concepts in various forms of mathematical representations can be seen in problem number 6 . In this indicator, the average score of the experimental class is also higher than the control class. Experimental class students are better able to present concepts in various forms of mathematical representation. However, the two students in the experiment and the control class have not been able to describe the problem as requested completely and correctly. This can be seen no one gets a score of 4 . Overall the experimental class is better than the control class for this indicator.

Indicators linking various concepts in mathematics and outside mathematics can be seen in problem number 7. On this indicator, the average score of control class students is higher than the experimental class. From Table 2 it can be seen that control class students are better at linking various concepts in differential equations. However, only a few people from the two sample classes got a perfect score. None of the experimental class students received a score of 4 , while the control class contained several students who received a score of 4 . This means that the two students in the sample class were still unable to link the concepts in differential equations with the outside world. Meanwhile, the indicator develops necessary conditions and / or sufficient conditions (question number 8 ). The average score of the experimental class students on this indicator is higher than the control class. Thus, it means that the ability to understand students' concepts in the experimental class on indicators develops necessary requirements and sufficient conditions is better than students in the control class. 
From the analysis of each of the concept understanding indicators above, it can be seen that descriptively, understanding the mathematical concepts of students whose learning using CORE learning models is better than understanding the mathematical concepts of students who use conventional learning.

Based on the results of hypothesis testing, the data obtained from the concept comprehension test in the two sample classes were not normally distributed because the Pvalue of the two sample classes was less than the real level $\alpha$ $=0.05$. Therefore hypothesis testing is done by U Mann Whitney test. Hypothesis testing shows that the average score of the understanding of the concept of experimental class students is better than the control class students. So it can be concluded that the ability to understand the concept of students who learn using the CORE model is better than students who use conventional learning.

\section{CONCLUSION}

From the results of the analysis and discussion above, it can be concluded that understanding the concept of students who learn using models of connecting, organizing, reflecting, and extending (CORE) better than students who use conventional learning. The connecting phase makes students recall old information and associate it with new information. In the organizing phase, the activities carried out were organizing ideas owned by students so that a new understanding of concepts was formed. Reflecting phase is very helpful for students in correcting their mistakes about the concepts they get. Finally, the extending phase by working on problem exercises makes better understanding of students' concepts.

\section{REFERENCES}

[1] Arslan, S. (2010). Traditional instruction of differential equations and conceptual learning. Teaching Mathematics and Its Applications, 29:94-107

[2] Czocher, Jennifer \& Baker, Greg. (2010). Contextual Learning in Math Education for Engineers. Proceeding International Conference on Engineering Education ICEE-2010 July 19-22, 2010, Gliwice, Poland

[3] Czocher, Jennifer. (2011). Examining the Relationship between Contextual Mathematics Instruction and Performance of Engineering Students. Proceeding International Conference on Engineering Education : 21-26 August 2011 : Belfast, Northern Ireland, UK

[4] Suherman, Erman. et. al. 2003. Strategi Pembelajaran Matematika Kontemporer. Bandung: JICA.

[5] Azizah, L. 2012. Pengembangan Perangkat Pembelajaran Model Core Bernuansa Konstruktivis Untuk Meningkatkan Kemampuan Koneksi Matematis. Unnes Jurnal Of Mathematics Education Research (ISSN 2252-6455). Universitas Negeri Semarang.

[6] Calfee. 2010. Increasing Teachers 'Metacognition Develop Students' Higher Learning During Content Area. Literacy Instruction: Findings From The Read -Write Cycle Project. California: Chapman Univercity.

[7] Iryanti, Puji. 2004. Penilaian Unjuk Kerja. Yogyakarta: Departemen Pendidikan Nasional (online) diakses tanggal 1 Juli 2016.

[8] Setyosari, Punaji. 2015. Metode Penelitian Pendidikan dan Pengembangan. Jakarta: PT Kharisma Putra Utama. 